\title{
Learning Management of UNP's Students and its Implication to Guidance and Counseling
}

\author{
Adnan Arafani ${ }^{1}$, Asmidir Ilyas ${ }^{2}$, Zikra $^{2}$ \\ ${ }^{1}$ Universiti Pendidikan Sultan Idris, Malaysia \\ ${ }^{2}$ Universitas Negeri Padang, Padang, Indonesia \\ *Corresponding author, e-mail: ariagunadharma@yahoo.co.id
}

\begin{abstract}
Learning management is process and activities to manage the learning efforts and to keep the achievable of goals. Leaning management is also associated with interaction in learning process with other human beings as well as with learning environment, learning outcomes and the objectives. This research is based on the problems that cause the delay of completing the study of organizational activists among students. The research method is quantitative with descriptive approach. Research subjects involved in this study were as many as 73 people. The instrument used is a questionnaire. From the results of the study noted that the overall ability of student learning management among student activists is in the category of "capable". This result study recommends campus' s leader to help the sustainability of " good" learning management, counseling lecturers and UPBK (campus' s counseling center) should provide appropriate services in maintaining good learning management and improve management skills for students who are still "less able" to manage their learning.
\end{abstract}

Keywords: Learning management, student activists, counseling

How to Cite: Arafani, A., Ilyas, A., \& Zikra, Zi. (2018). Learning Management of UNP's Students and its Implication to Guidance and Counseling. International Journal of Research in Counseling and Education, 2 (2) 51- 57, http://doi.org/10.24036/0022za0002

\section{Introduction}

In the national education system law (Sisdiknas) No. 20 of 2003 explained that Education is a conscious and planned effort to create an atmosphere of learning and learning process so that learners actively develop their potential to have spiritual strength, self-control, personality, intelligence, excellent character, as well as skills needed by him and by the society. Base on this definition, it is clear that the education must be planned and conscious with the aim to create a condition that allows the student to develop their self. The expected results in this process are sequentially stated that spiritual religious potential is the main goal, then selfcontrol ability, good personality, intelligence, excellent character and daily skills.

To organize education in Indonesia, the government designed education starting from elementary school (SD), junior high school (SMP), Senior High School (SMA) and continued with Higher Education level.

Regarding to higher education level, in the regulation No. 20 of 2003 of National Education System (Sisdiknas) chapter 19 and 20 regulated about higher education, clearly stated that higher education is education after secondary education which includes diploma education program, bachelor degree, master degree, specialists, and doctoral degrees organized by higher education institution.

Students at higher education level are called " mahasiswa" . According to their development, University students are classified as late adolescence and early adulthood, ie age 18-21 years and 22-24 years. At this stage of age, the students experience a transition from late adolescence to early adulthood (Gunawati \& Hartati, 2006). This period has abundant energy to perform many kinds of activities, so the campus is designed to provide student organizations as a channel to channel interest and talent in order to accommodate their potential. 
While studying in college, some students are involved in the student organizations committee. There are several student organizations in a university such as Student Representative Council (MPM), Student Executive Board (BEM), Student Activities Unit (UKM), Student-Faculty Executive Board (BEM F), StudentFaculty Representative Body (BPM F), Student Department Association (HMJ) and so forth. In fact, not all students are able and willing to engage in organizational activities, as recorded in the data of BAAK (Administrative Bureau and academic) of UNP in 2013, the participation of active students in student organizations is only ranges from $4-5 \%$ only from the total number of enrolled students at State University of Padang. Students who undergo lectures and concurrently in the activities of student organizations certainly spend more time and energy than students in carrying out their duties in academic activities only, this further demands good self-management capabilities.

Through self-management, individual behavior is well managed (Hamzah B. Uno, 2006: 219). The Liang Gie (2001: 188) explains self-management is pushing self forward, organizing all elements of personal potential such as controlling the will to achieve good things and developing abilities in various aspects of personal life. Lectures, teaching and learning process of a student who is active in the a of the organization will not be disturbed if the concept of self-management is good because self-management makes students independent and able to organize their future. Students with good self-management are able to control their will, to arrange the schedule in such a way and to make afford in order to get good grades and appropriate study periods. In the problem-solving issue, students who have good self-management will be able to solve problems faced related to academic as well as to the organization.

On the other hand, learning is essentially an activity done consciously to produce a change, involving knowledge, skills, attitudes, and values (Hamzah, 2009: 54). Oemar Hamalik (2003: 154) defined learning as a relatively steady change in behavior emerged from practicing and experiencing new things. The ability of self-management in learning is a separate specification in achieving success in the university level.

Ability to manage learning activities at universities according to Oemar Hamalik (8: 2003) implicitly stated in the learning management functions namely; planning, mobilization, organizing, coordination, supervision, supporting elements and assessment. This learning management function also contains aspects of learning strategies, such as repetition, elaboration, organization and metacognitive methods. Given the importance of learning strategies in lectures, Triave Nuzila Zahri (2013) advises students to improve learning strategies through such strategies as repetition, elaboration, organization and metacognitive. Good learning management as part of self-management has a significant relationship with learning outcomes, Vinda Chairunnisa (2013: 75) in his research concluded that students who have high self-management will get high learning outcomes also and vice versa.

During the period of study in college, there are some students who are active in student organizations activities. The intensity of activeness of a student in campus internal organization can be accessed from the intensity of a person in following the series of events of the organization, but to further simplify the activeness in the organization is based on the official acknowledgment to an individual in the organization committee.

Since July 2, 2013, researchers have observed various fact and phenomena from BEM UNP committee member for the period of 2013-2014, the phenomenon found is there some of the committee member of BEM UNP who is able to complete the lectures on time while he is actively involved in the committee, but there are also members who still have the credit to be done and they should have to commit the final project. In other words, they supposedly are late to finish their studies on time or suffering "congestion" . The researchers interviewed several organization members on March 21, 2014, and there were BEM UNP members who did not make a learning plan, some were not able to motivate themselves so that they were stalling the task and there was also a tendency to blame the condition for the problems.

This indicates that there are differences in the solving of academic problems for students who are active in student organizations such as BEM, many things are behind this condition such as unplanned learning activities or inadequacy in utilizing supporting facilities such as textbooks in the library, internet access, and academic advisor. The existence of congestion among students is not caused by a low intellectual ability, explained by Dedi Supriadi in Asmidir Ilyas (2010: 3) that:

" The main cause of many congestions is not solely due to the weakness of the students in terms of intellectual prowess, but because there are barriers that come from adjustment and socio-emotional disturbance, and lack of motivation. In addition, institutional factors derived from universities where students learn to participate determine the success or failure of student studies, such as teaching and learning process, facilities, seriousness of lecturers, curriculum, examination system, student accommodation, etc.:" 
Another phenomenon of the researcher also observed is the existence of bad communications skill with learning group so that result of the group task is not resolved well together.

In addition, there are also BEM members whose attention to the tasks of the organization is so great so that the attention and motivation to do the lecture tasks become small and no longer eager to come to class to undergo classical learning activities. If the problem of completing lectures for students who are active in this organization remains left unchecked will result in delays in completion of studies, more spending money in tuition fee, elicits the negative perception of students who are actively organizing, and other negative effects.

Furthermore, the researcher takes more attention on the learning management of BEM UNP committee members. Researcher observed the BEM UNP committee made the task in the office of BEM UNP, and some members even completed the research proposal and preparing the thesis in the office of BEM UNP, sometimes there are bringing their study group to do tasks in the secretariat BEM UNP, among the member also there are leader of the study group and as a center for the coordination of its learning members, the availability of wifi and spacious room is also used well by the committee member.

The busyness of the member with a variety of organizational activities both work programs and non-work programs make the availability of time to learn for them becomes increasingly narrow compared to students who do not participate in the committee of student organizations. Urgent conditions or important tasks of the organization allow these active students not to attend face-to-face courses on certain subjects. Based on the explanation and some of the above problems, the researcher is interested to conduct this research.

\section{Method}

This research uses the quantitative method with descriptive approach. Research subjects involved in this study were as many as 73 people. The instrument used for data collection in this study is a questionnaire. In descriptions of the data researcher used presentation formula. Data processing is also done by Microsoft office excel 2013.

\section{Results and Discussion}

Based on the results of data processing, the overall results on the learning management of UNP students who are active in the organization can be seen as follows:

\begin{tabular}{|l|l|l|l|}
\hline \multirow{2}{*}{ NO } & \multirow{2}{*}{$\begin{array}{l}\text { Learning } \\
\text { Management } \\
\text { Category }\end{array}$} & \multicolumn{2}{|l|}{$\begin{array}{l}\text { Learning } \\
\text { Management }\end{array}$} \\
\cline { 3 - 4 } & F & $\%$ \\
\hline 1 & very capable & 32 & 43.84 \\
\hline 2 & capable & 40 & 54.79 \\
\hline 3 & Less capable & 1 & 1.37 \\
\hline 4 & unable & 0 & 0.00 \\
\hline
\end{tabular}

Table 1

Recapitulation of Learning Management of Student who is active in Organization

$\mathrm{N}=73$

Based on the above table, it appears that most of the students who are active in the organization, particularly in BEM UNP have a good learning management skills, as many as $54.79 \%$ capable, while $43.84 \%$ of students are categorized as very capable and as many as $1.37 \%$ classified as less capable.

Furthermore in the sub-variables " make learning planning" , as much as $60.27 \%$ students are very capable, $38.36 \%$ are able and $1.37 \%$ described as less able. In the sub-variable of " self-motivating" , $91.78 \%$ of students who are active in BEM UNP is very capable of motivating himself and $8.22 \%$ other included in the category of able. In the sub-variables Coordination of learning activities as much as $67.12 \%$ is very capable, as many as $31.51 \%$ pertained and, nevertheless found as much as $1.37 \%$ is still less able. Further, sub-variable 
utilizes this supporting element as much as $43,84 \%$ student active in BEM UNP very capable, $53,42 \%$ categorized able and 2,74\% still less able. In the sub-variable evaluate proved $2.74 \%$ students who are active in BEM UNP less able to carry out the assessment, $43.84 \%$ are capable and $53.42 \%$ are very capable.

\section{Learning Management in Preparing a Learning Plan}

Based on the results of the study, students who are active in BEM UNP are very able to arrange the learning plan. This means that some UNP students who are active in the organization have excellent ability to plan the learning activities with percentage $60,27 \%$ and student which is categorized as capable as much as $38,26 \%$ while there are students who are classified as less capable: $1.37 \%$.

According to Oemar Hamalik (2010: 08) to develop a good learning plan, students need to be familiar with the education program, curriculum packages in the study program or department, and the preparation of the plan itself. For students who are active in the organization, recognizing educational programs, curriculum packages, and courses and using planning techniques is not a difficult thing because students who are active in organizations are required to spend time effectively and use effective strategies that can help them. This is due to the demands they have more such as the demand to use the time not just to learn, but also to organize all the tasks and activities of the organization. The demands of using the time to learn and to work in the organization make the individuals have a good self-regulated learning. Mustika Dwi Mulyani (2013: 46) argues that awareness of self-esteem, the desire to try, commitment, time management, efficient use of strategy are the most fundamental factors of self-regulated learning.

\section{Learning Management in Self-Motivating}

Based on the data processing the learning management of student activist concerning self-motivation can be categorized as very capable with the percentage of $91.78 \%$ and others $8.22 \%$ are categorized able. This indicates that students who are active in the organization already have good achievement desires; it is seen from confidence for success, family encouragement, school, and friends. The emergence of achievement motivation is shaped by the presence of intrinsic and extrinsic factors that are beliefs for success, selfefficacy, value, and beneficial experience gained previously. While extrinsic factors include family, school, and friends. (Ratna Haryani and M.M.W. Tairas, 2014: 2)

\section{Learning Management in Coordination of Learning Activities}

The ability to coordinate learning activities, either in coordinating with other colleagues and the communicating about the subject with the lecturers are a form of learning management in sub-theme of coordination of learning activities (Oemar Hamalik, 2010: 8). Based on the results of this study, it is seen that most of the students who are active in BEM UNP organization have excellent ability in coordinating learning activities, seen in percentage as much as $67,12 \%$. In addition, the other $31.51 \%$ are capable and only $1.37 \%$ are classified as less capable.

This is understandable because there are three main benefits that students receive from organizing that is the opportunity to expand the association and get many friends, the opportunity to learn and expand experience about the organization, and the opportunity to add insight and knowledge of new things (Leny and Suyasa, 2006: 93). The experience of hanging out with many people and with plural personality enrich the ability of communication and coordination which strengthen the learning management.

The results of this study also show that not less than $1.37 \%$ of students are still less able to coordinate learning activities well, this finding supposedly due to the fact that there some first-year student in the organization member.

\section{Learning management in Utilizing Supporting Elements.}

Ability to utilize supporting elements such as facilities and learning equipment that has been available is also a sub-theme of learning management. Elements of support can improve students' ability in carrying out learning activities (Oemar Hamalik 2010: 8).

Based on the findings of research students' learning management capabilities that are active in organizational activities concerning the ability to supporting utility element in general categorized as able (53.42\%) others $43.84 \%$ are very capable and there are $2.74 \%$ who are still less able. It can be understood that 
in the committee there is always activities of many students who reduce the additional time of study so that the time to consult with academic supervisors also become very limited, whereas consulting with the lecturer of PA (academic supervisor) is expected to cope with the problem of college students who, if not faced seriously will lead to student congestion. (Asmidi Ilyas, 2010: 8)

Supporting elements that are widely used by students at this time is the internet, as a source of learning and media interact with friends (Laila, 2006: 2). The availability of internet in the office of the organization is very helpful for students who are active in the organization to support the lectures.

\section{Learning management in doing assessment}

Based on the result of the research, it can be seen that most of the students who are active in BEM UNP have the ability of learning management related to the assessment which is in the very capable category ( $52.42 \%$ ). Other $43.84 \%$ classified as capable and there are $2.74 \%$ who are still less able.

The ability to carry out assessments, whether assessed by lecturers or self-assessment is a feature of learning management in part of assessment skill (Oemar Hamalik 2010: 8). Students who are involved in the activities of student organizations benefit from the formation of mature and adult personalities (Leny and Suyasa, 2006: 93), this encourages students who are active in the organization to evaluate its performance both in the organization and in daily life issues.

\section{Implications of to Guidance and Counseling Services}

Lecturers BK / Counselor, especially who served in the Unit Counseling Guidance Services in the university need to provide guidance and counseling services to develop student learning management to be more increased and evenly.

Developing student learning management skills is one of the efforts to make students become independent, able to maximize the ability and utilize facilities, as Prayitno and Erman Amti (2004: 99) describe guidance is the process of providing assistance made by an expert person to someone or some individuals both children, adolescents, and adults so that the guided person can develop his or her own ability and independently by harnessing the power of individuals and existing means and can be developed based on the prevailing norms. Thus it is clear that the effort of developing students' learning management capability is one of the responsibilities of counselors.

In addition, through guidance and counseling activities students are expected to gain the achievement as optimal as possible. As explained by Achmad Juntika and Nurihsan (2006: 91) guidance and counseling in universities is an effort to help students to develop themselves and overcome academic problems and socialpersonal problems that affect their academic progress. The guidance includes academic guidance services provided by an academic supervisor at the department/program level, and counseling session provided by guidance and counseling teams at the department/course, faculty and university levels.

The various conditions of student learning management that are active in the organization can be described by using one of the guidance counseling tools that is Alat Ungkap Masalah seri Mahasiswa (Prayitno et al, 1997: 9)

The services that can be provided to students who are active in organizational activities can be provided through:

1. In general by the lecturer Academic Advisor (PA)

\section{Specifically: Counseling Service Unit (UPBK)}

For UPBK, the need of students who are active in the organization to improve their learning management skills should be an opportunity to widen the usefulness of counseling guidance services in universities. Among the services that can be done are:
a. Content Mastery Service (layanan penguasaan konten)
b. Group counseling
c. Individual counseling. 


\section{Conclusion}

1. Students who are active in organizational activities are categorized as very capable of managing learning planning.

2. Students who are active in organizational activities are categorized as very capable in managing selfmotivation.

3. Learning management students who are active in organizational activities, regarding the ability to coordinate learning activities are categorized as very capable.

4. Learning management of student who is active in the activities of the organization regarding the ability to utilize supporting facilities pertained pertinent.

5. With regard to the ability to carry out assessments in learning management, active students in organizational activities are categorized as highly capable.

Based on the results of research that has been elaborated, it can be put forward some suggestions as : to establish optimal learning management for students who are active in the organization, it is expected for UPBK to holds " content mastery services" about learning management for student activist (Ardi, Ibrahim, \& Said, 2012; Ardi \& Sukmawati, 2017; Ardi \& Yendi, 2017; Daharnis \& Ardi, 2016). This can be recommended to the Vice Rector III in order to become a compulsory subject in Basic Training of Organization or Leadership Training and Student Management of every student organization that is on campus. The learning management materials can be taken from the Skills Training Series book. Another recommendation is; it is necessary to apply the recommendation letter from PA lecturer for each candidate of the organization. It is intended that the lecturer supervising academic data to control the development of learning development.

\section{References}

Achmad Juntika Nurihsan. 2006. Bimbingan Dan Konseling Dalam Berbagai Latar Kehidupan.Jakarta : Reftika Aditama.

Asmidir Ilyas. 2010. Penyebab Kongesti Mahasiswa: Implikasinya bagi Penasehat Akademik Mahasiswa (PAM) dalam Melaksanakan Tri Dharma Perguruan Tinggi.Makalah tidak diterbitkan, Disampaikan pada Seminar Nasional dan Workshop Profesi Bimbingan Dan Konseling Tanggal 9 Januari 2010:BK FIP UNP

Ardi, Z., \& Sukmawati, I. (2017). Social Media and the Quality of Subjective Well-Being; Counseling Perspective in Digital Era. Open Science Framework. October, 15.

Ardi, Z., \& Erlamsyah, E. (2017). Peningkatan Kualitas Penulisan Artikel Ilmiah bagi Kepala Sekolah. Jurnal Aplikasi IPTEK Indonesia, 1(1), 25-34.

Ardi, Z., \& Yendi, F. M. (2017). Students Attitude Towards LGBTQ; the Future Counselor Challenges. Jurnal Konseling dan Pendidikan, 5(2), 74-79.

Ardi, Z., Ibrahim, Y., \& Said, A. (2012). Capaian Tugas Perkembangan Sosial Siswa dengan Kelompok Teman Sebaya dan Implikasinya terhadap Program Pelayanan Bimbingan dan Konseling. Konselor, 1(2).

Daharnis, D., \& Ardi, Z. (2016). The Compatibility Student Choice of University Majoring; a Preliminary Studies. GUIDENA: Jurnal Ilmu Pendidikan, Psikologi, Bimbingan dan Konseling, 6(1), 101-109.

Depdiknas. 2003. Undang- undang No. 20. Tahun 2003 Tentang System Pendidikan Nasional. Jakarta: Depdiknas

Hamzah B Uno. 2009. Teori Motivasi dan Pengukurannya: Analisis di Bidang Pendidikan. Jakarta: Bumi Aksara.

Laila. 2006. Pemanfaatan Internet Bagi Perkuliahan Mahasiswa Pascasarjana Medan : UNIMED Press

Leny \& P. Tommy Y.S. Suyasa. 2006.Keaktifan Berorganisasi dan Kompetensi Interpersonal. Jurnal Fakultas Psikologi Universitas Tarumanagara Vol 8, No. 1, 71-99.

Mustika Dwi Mulyani.2013.Hubungan antara Manajemen Waktu dengan Self Regulated Learning pada Mahasiswa. Jurnal Universitas Negeri Semarang, Indonesia EPJ 2 (1) (2013) diambil dari http://journal.unnes.ac.id/sju/index.php/epj pada 28 Januari 2014

Oemar Hamalik. 1995. Pengembangan Sumber Daya Manusian Manajemen Ketenaga Kerjaan Pendekatan Terpadu. Jakarta: Bumi Aksara. 
Oemar Hamalik. 2003. Manajemen Belajar di Perguruan Tinggi.Jakarta:Sinar Baru Algesindo

Oemar Hamalik. 2010. Manajemen Belajar di Perguruan Tinggi.Jakarta:Sinar Baru Algesindo

Prayitno dan Erman Amti. 2004. Dasar-dasar Bimbingan dan Konseling. Jakarta: Rineka Cipta.

Prayitno Dkk. 1997. AUM PTSDL FORMAT 1 : MAHASISWA. Student Support Services And Career Planning Development Proyek PGSM Direktorat Jendral Pendidikan Tinggi Departemen Pendidikan Dan Kebudayaan. Padang : UNP Press

Prayitno, dkk. 1997. Seri Pemandu Pelaksanaan Bimbingan dan Konseling di Sekolah - Pelayanan Bimbingan dan Konseling SMU.Padang : Bina Sumberdaya MIPA

Ratna Haryani dan M.M.W. Tairas.2014. Motivasi Berprestasi pada Mahasiswa Berprestasidari Keluarga Tidak Mampu Secara Ekonomi. Jurnal Psikologi Pendidikan dan Perkembangan Vol 3 , No. 01, April 2014 Departemen Psikologi Pendidikan dan Perkembangan Fakultas Psikologi Universitas Airlangga. Surabaya.

Restu, Y., Yusri, Y., \& Ardi, Z. (2013). Studi Tentang Perilaku Agresif Siswa di Sekolah. Konselor, 2 (1).

The Liang Gie. 2001. Cara Belajar yang Efisien. Yogyakarta: Liberty.

Triave Nuzila Zahri. 2013. Strategi belajar mahasiswa bimbingan dan konseling fakultas ilmu pendidikan angkatan 2011.Skripsi tidak diterbitkan.BK FIP UNP

Vinda Chairunnisa. 2013. Hubungan antara Manajemen Diri dengan Hasil Belajar Siswa di Sma N 1 Sungayang.Skripsi tidak diterbitkan: BK FIP UNP 